clinical significance. One-fifth of its pages is given over to a copious index and to more than 1,500 full bibliographical references. This makes it an excellent work of reference. However, though it appeared in 1961, it appears that it was finished several years before then Wilkinson's book soems to be written more with the view of bench work and is much more up to date. It has excollent brief résumés on subjocts such as "onzyme tests in myocardial infaretion", "onzyme tests in liver diseases", "diagnostic applications of isoenzymo separation". If tho purso will allow it, many laboratory workers will find it well worth thoir whilo to aequiro both.

H. LehmanN

\section{BIOCHEMISTRY AT THE MOLECULAR LEVEL}

\section{Comprehensive Biochemistry}

Edited by Prof. Marcel Florkin and Prof. Elmer H. Stotz. Vol. 2: Organic and Physical Chemistry. Pp. xii +328. (Amsterdam and New York: Elsovier Publishing Company, 1962.) $80 s$.

$\mathrm{T}$ HERE is a wind of change blowing through biochemistry. Those who welcome it as a refreshing breeze will appreciate the appearance of the first volume (actually Volume 2) of this advanced treatise on biochemistry. In the past, biochemists had been concerned with determining what reactions occur in living organisms; but more recently, interest has been focused on the mechanism of biological processes at the molecular level. The present volume reflects this type of approach to biochemistry.

A novel feature is the decision to publish the treatise in fivo soctions, each of which will comprise several smal volumes. It is claimed that this will have soveral advan. tages. The specialist will be able to purchase only those sections which are of particular interest to him; future revision of volumes will be simpler; individual volumes will not be badly out of dato when thoy appear. It may be noted that, in support of the last point, there are numerous references to papers published in 1960 .

The present volume is devoted to organic and physical chemistry and opens with a chapter of some 200 pages by M. L. Bender and R. Breslow on the mechanisms of organic reactions. Both authors are well known for their investigations of the mechanisms of enzyme catalysis and both write in a clear, concise style. They describe the kinotic and mechanistic aspocts of all the main types of reactions of organic compounds which are relevant to biochemistry, including nucleophilic substitution in aliphatic systoms, elimination and addition reactions involving carboncarbon doublo bonds, nucloophilic reactions of carboxylie and phosphoric acid derivatives, addition to carbonyl groups, enols and their relevance to various types of condensation reactions, carboxylation and decarboxylation, aromatic substitution, and various types of oxidation-reduction reactions. Where possible, the authors illustrate the several reactions with examples of biochemical import. In addition, particular attention is paid to the mechanism of action of simplo catalysts and their possible relevance as modols for the more complex catalysis by enzymes.

Tho remaining two chapters are writton by W. D. Stein. The first of these doals with the equilibria of solutions, while the second treats problems such as diffusion and osmosis, which involve movement of molecules and ions within solutions and across membranes. The author presents his subject logically and attractively by starting with ideal solutions of non-electrolytes and developing the treatment progressively for non-idoal bohaviour, solutions of electrolytes, and finally for macromolecules. No attempt is made to give rigorous matho- matical proofs of equations, but there are adequate references for the more determined reader. The pattern of the final chapter on diffusion and osmosis is similar. After dealing with Fick's laws of diffusion, the relation. ships between diffusion coefficients on one hand and molocular weight and viscosity coefficient on the other are discussed. Consideration of more complex systoms involving large solutes, electrolytes, concentrated solutions, and the presence of membranes follows naturally.

I myself should have liked to see this book open with a short chapter on classical thermodynamies and the thermodynamies of irreversible processes. Thr. latter topic has beon noglectod in biochernical text-books, and it would have formed a bridge betwoon the static and dynamic aspects of biochomical processes. It is to be hoped that the editors will find room later in this treatise to rectify this deficiency.

D. 'T. ELMORY

\section{RESIN CHEMISTRY}

\section{Alkyd Resin Technology}

Formulating Tochniques and Allied Calculations. By T. C. Patton. (Interscience Manuals No. 8.) Pp. ix + 197. (London and New York: Interscience Publishers. Division of John Wiley Inc., 1962.) 74s.

$\mathrm{T}$ HIS book is specifically designed to cover a quantitative approach to the formulation and design of alkyd resins. It does so in a manner such that some theorotical background is stated and, from this, formulæ are derived and illustrations worked out to make porfectly clear the steps which are taken in the development of a comprehensive scheme to cover the very wide field of alkyd rosins. In putting forward his main thesis, namely the application of an alkyd constant based on Carother's classical work, the author has displayed a wide experience and his book has been written with an aptitude to explain in simple language what is, in effect, an exceedingly complex subject. The use of this constant permits the formulator to design a satisfactory alkyd or to offect adjustments where necessary.

Porhaps it is inevitable in a mathematical treatiso of this type that simplifications have to be made. In the technological field this may be permitted even if, from a purist. point of viow, there are a number of postulates which are less acceptable. Examples of these are, tho differentiation of acid and monoglyceride alkyds based on attaching the fatty chain at the bota- and alpha-positions respectively (p. 20), or the postulates (p. 74) arising from the reaction of the alpha and beta glycerol groups which assume that the alpha groups react completely before the beta groups, giving linear polymers.

Again, of the four formulx systems discussed in detail is one concerning $M_{A V}$, the average molecular weight of the alkyd at gelation. No distinction is made of the big difference between the weight average and the number average molecular weight. When dealing with physical concopts such as gelation, it is the latter which dominates the system. Nevertheless, from a practical point of view, the validity of the foregoing concept is shown to hold for many alkyds of known behaviour. It covers also urethane oils, water-soluble alkyds and modifications with othor polymors such as styrene.

No major attempt is made, or has been intended, to describe procoss work or the influence of temperature on many of these results, but such factors will be familiar to the plant chemist.

A comprehensive bibliography is given at the end of the book drawn largely from American sourcos. It is gratifying to note several references to British work.

The resin chomist will find stimulus and much to help him in his calculations from this volume. It should find a place in the library and on the bench of many laboratories.
A. I. Escolme 